\title{
Interaksjoner med metadon og buprenorfin
}

\author{
LAR-behandling i Norge omfatter rundt 5000 pasienter, hvorav ca. $60 \%$ \\ får metadon og ca. 40 \% får buprenorfin. Et økende antall fastleger \\ og sykehusleger kommer i kontakt med slike pasienter. I artikkelen \\ presenteres en kortfattet oversikt over medikamentelle interaksjoner \\ med metadon og buprenorfin. Sammenfatningen kan være til hjelp for \\ legen i den daglige kontakt med disse pasientene.
}

Se også kunnskapsprøve på www.tidsskriftet.no/quiz

Som de fleste legemidler er metadon og buprenorfin gjenstand for interaksjoner, både farmakokinetiske og farmakodynamiske. Farmakokinetiske interaksjoner finner i hovedsak sted ved påvirkning av cytokrom P-450-systemet (CYP-systemet), hemming og induksjon av de aktuelle CYP-enzymer, og da særlig CYP3A4 (tab 1) vil potensielt kunne henholdsvis øke og senke serumkonsentrasjonen av metadon og buprenorfin. Ved samtidig behandling med svært sterke hemmere av CYP3A4 kan konsentrasjonen av metadon øke inntil to ganger, mens buprenorfinkonsentrasjonen kan øke 2-5 ganger. Samtidig bruk av CYP3A4-induktorer på den annen side kan gi en reduksjon av serumkonsentrasjonen av metadon og buprenorfin med $50-80 \%$ (1). Mens enzymhemming opptrer umiddelbart, vil enzyminduksjon

\begin{tabular}{|c|c|}
\hline Hemmere & Indusere \\
\hline Cimetidin & Karbamazepin \\
\hline Ciprofloksacin & Efavirenz \\
\hline Diltiazem & Fenytoin \\
\hline Erytromycin & Johannesurt \\
\hline Flukonazol ${ }^{1}$ & Nevirapin \\
\hline Fluoksetin & Rifampicin \\
\hline \multicolumn{2}{|l|}{ Fluvoksamin } \\
\hline \multicolumn{2}{|l|}{ Grapefruktjuice } \\
\hline \multicolumn{2}{|l|}{ Itrakonazol'1 } \\
\hline \multicolumn{2}{|l|}{ Ketokonazol } \\
\hline \multicolumn{2}{|l|}{ Klaritromycin } \\
\hline \multicolumn{2}{|l|}{ Paroksetin } \\
\hline \multicolumn{2}{|l|}{ Posakonazol ${ }^{1}$} \\
\hline \multicolumn{2}{|l|}{ Venlafaksin } \\
\hline \multicolumn{2}{|l|}{ Verapamil } \\
\hline \multicolumn{2}{|l|}{ Vorikonazol ${ }^{1}$} \\
\hline
\end{tabular}

først opptre etter en til to uker. Det er imidlertid ikke gitt at en kjent hemmer eller induser av noen av de aktuelle enzymene vil gi endringer i serumkonsentrasjon, langt mindre klinisk relevante endringer. Siden metadon og buprenorfin begge har dempende effekter på sentralnervesystemet, vil samtidig inntak av andre sentraldempende legemidler og alkohol kunne gi additive dempende effekter, med sedasjon og respirasjonshemming. Dette, samt det faktum at metadon i likhet med en rekke andre legemidler kan føre til forlenget QT-tid, er de farmakodymamiske interaksjonsmekanismene det er viktigst å være oppmerksom på.

\section{Materiale og metode}

Artikkelen er basert på et ikke-systematisk litteratursøk i Medline, med et skjønnsmes- sig utvalg av artikler basert på forfatternes erfaring innen feltet.

\section{Farmakokinetikk}

Metadon er en syntetisk fremstilt opioidagonist med en halveringstid på 5-50 timer, men som vanligvis ligger i området 24-36 timer. Metadon absorberes raskt, og har en biotilgjengelighet på 40-95\% ved peroral administrasjon. Maksimum serumkonsentrasjon nås etter 1-6 timer (vanligvis innen 2-4 timer). Metadon metaboliseres i hovedsak av CYP3A4 i leveren, samt noe i tynntarmen. CYP3A4 har ingen kjente polymorfismer, men det er store individuelle forskjeller $\mathrm{i}$ aktiviteten til enzymet og $\mathrm{i}$ oppnådd serumkonsentrasjon etter inntak. I tillegg til CYP3A4 er CYP2D6 og CYP1A2 involvert $\mathrm{i}$ metabolismen $\mathrm{i}$ mindre grad (fig 1). Ved basisk urin vil utskillingen bli kraftig hemmet, og halveringstiden forlenget inntil det dobbelte (2). Det definerte terapeutiske området for metadon ligger på 600-1 $200 \mathrm{nmol} / 1$, og serumkonsentrasjonsmålinger kan være nyttig for å kartlegge forholdet mellom dose, plasmakonsentrasjon og effekt, samt for å oppdage eventuelle farmakokinetiske interaksjoner.

Buprenorfin er et semisyntetisk tebainderivat, og er en partiell agonist til $\mu$-opioidreseptoren, mens den til $\kappa$-opioidreseptoren er 


\section{Hovedbudskap}

- Hemmere og induktorer av CYP3A4 kan henholdsvis øke og senke serumkonsentrasjonen av metadon og buprenorfin

- Samtidig behandling med benzodiazepiner og andre dempende legemidler $\emptyset k e r$ faren for sedasjon og respirasjonshemming

- I store trekk er medikamentinteraksjoner av større klinisk betydning for metadon enn for buprenorfin

en antagonist. Da buprenorfin har en lav oral biotilgjengelighet, administreres den som regel sublingvalt, der det er rapportert at $20-50 \%$ av stoffet når den systemiske sirkulasjonen. Maksimum serumkonsentrasjon nås etter 40 minutter til 3,5 timer (vanligvis innen 1-2 timer), og høy lipidløselighet sørger for en rask passasje av blod-hjerne-barrieren. Ved sublingval administrasjon ligger halveringstiden vanligvis på 20-40 timer, men kan være kortere eller lengre. Buprenorfin metaboliseres i leveren av CYP3A4 (fig 1), i hovedsak til norbuprenorfin, som er en aktiv metabolitt. Buprenorfin skilles ut av kroppen i uomdannet form i større grad enn metadon, slik at metabolisering i lever er av noe mindre betydning for buprenorfin enn for metadon $(3,4)$. Serumkonsentrasjonsmålinger er mindre anvendelig for buprenorfin enn for metadon, men også her kan målinger være en indikator for farmakokinetiske interaksjoner. Relasjonen mellom effekt og konsentrasjon ved høye doser er uklar, og eventuelle interaksjoner vil ikke nødvendigvis føre til klinisk relevante effekter.

\section{Interaksjoner med noen aktuelle medikamentgrupper (tab 2)}

Antidepressiver og antipsykotika

Paroksetin, som er en hemmer av CYP2D6, er vist å kunne øke konsentrasjonen av metadon (dog ikke hos langsomme metaboliserere av CYP2D6) (5). Sertralin er vist å kunne gi en liknende økning av metadonkonsentrasjonen (6). Det er in vitro vist at CYP3A4-hemmere som fluvoksamin og fluoksetin kan øke konsentrasjonene av metadon og buprenorfin (7). Trisykliske antidepressiver og antipsykotika med dempende effekter kan potensielt øke de sederende egenskapene til metadon og buprenorfin.

For metadon er det særlig to farmakodynamiske interaksjoner det kan være verdt å merke seg: Da metadon er en svak serotoninreopptakshemmer, kan samtidig behandling med MAO-hemmere (moklobemid) potensielt gi serotonintoksisitet og serotonergt syndrom (8). Det er etter hvert vist at metadon kan føre til forlenget QT-tid og torsades de pointes (9) med mulig dødelig utfall. Trisykliske antidepressiver og flere antipsykotika (tab 2) kan i
Tabell 2 Interaksjoner med metadon og buprenorfin og noen legemiddelgrupper/legemidler, noen relevante eksempler. Effekt på serumkonsentrasjon av hhv. metadon og buprenorfin: ( $\uparrow$ ) $\emptyset k e r,(\downarrow)$ senker, $(\uparrow \downarrow) \varnothing k e r / s e n k e r,(-)$ ingen effekt. Dempende effekt på sentralnervesystemet: En rekke legemidler utover dem som er nevnt i tabellen, kan gi forlenget QT-tid

\begin{tabular}{|c|c|c|c|c|}
\hline & \multicolumn{2}{|c|}{ Metadon } & \multicolumn{2}{|c|}{ Buprenorfin } \\
\hline & \multicolumn{2}{|c|}{ Interaksjoner } & \multicolumn{2}{|c|}{ Interaksjoner } \\
\hline & Kinetiske ${ }^{1}$ & Dynamiske² & Kinetiske ${ }^{1}$ & Dynamiske ${ }^{2}$ \\
\hline \multicolumn{5}{|l|}{ Antidepressiver } \\
\hline Paroksetin & (个) CYP2D6 & - & $(-)$ & - \\
\hline Sertralin & $(\uparrow)$ CYP2D6 & - & $(-)$ & - \\
\hline Fluvoksamin & (个) CYP3A4 & - & ( $\uparrow)$ CYP3A4 & - \\
\hline Fluoksetin & (个) CYP3A4 & - & (१) CYP3A4 & - \\
\hline TCA & $(-)$ & $\begin{array}{c}\text { Forlenget QT-tid } \\
-\end{array}$ & $(-)$ & - \\
\hline Moklobemid & $(-)$ & $\begin{array}{c}\text { Serotonintoksisitet } \\
-\end{array}$ & $(-)$ & - \\
\hline \multicolumn{5}{|l|}{ Antipsykotika } \\
\hline Klorpromazin & $(-)$ & $\begin{array}{c}\text { Forlenget QT-tid } \\
-\end{array}$ & $(-)$ & - \\
\hline Amisulprid & $(-)$ & Forlenget QT-tid & $(-)$ & - \\
\hline Quetiapin & $(-)$ & Forlenget QT-tid & $(-)$ & - \\
\hline Ziprazidon & $(-)$ & $\begin{array}{c}\text { Forlenget QT-tid } \\
-\end{array}$ & $(-)$ & - \\
\hline Olanzapin & $(-)$ & Forlenget QT-tid & $(-)$ & - \\
\hline Haloperidol & $(-)$ & $\begin{array}{c}\text { Forlenget QT-tid } \\
-\end{array}$ & $(-)$ & - \\
\hline Flupentixol & $(-)$ & $\begin{array}{c}\text { Forlenget QT-tid } \\
-\end{array}$ & $(-)$ & - \\
\hline \multicolumn{5}{|l|}{ Antiepileptika } \\
\hline Karbamazepin & $(\downarrow)$ CYP & - & ( $\downarrow)$ CYP3A4 & - \\
\hline Fenytoin & (ฟ) CYP & - & ( $\downarrow)$ CYP3A4 & - \\
\hline Fenobarbital & (ฟ) CYP & - & 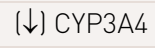 & - \\
\hline \multicolumn{5}{|l|}{ Antibiotika } \\
\hline Ciprofloksacin & $\begin{array}{l}\text { ( } \uparrow \text { ) CYP3A4, } \\
\text { CYP1A2 }\end{array}$ & $(-)$ & $(-)$ & $(-)$ \\
\hline Erytromycin & $(\uparrow)$ CYP3A4. & Forlenget QT-tid & ( $\uparrow$ ) CYP3A4 & $(-)$ \\
\hline Claritromycin & (个) CYP3A4. & Forlenget QT-tid & ( $\uparrow)$ CYP3A4 & $(-)$ \\
\hline Azitromax & $(-)$ & Forlenget QT-tid & $(-)$ & $(-)$ \\
\hline \multicolumn{5}{|l|}{ Antimykotika } \\
\hline Flukonazol & $(\uparrow)$ CYP3A4 & $(-)$ & $(-)$ & $(-)$ \\
\hline Ketokonazol & (个) CYP3A4 & $(-)$ & ( $\uparrow)$ CYP3A4 & $(-)$ \\
\hline Antiretrovirale midler & $(\uparrow \downarrow)$ & $(-)$ & $(\uparrow \downarrow)$ & $(-)$ \\
\hline Benzodiazepiner & $(-)$ & - & $(-)$ & - \\
\hline
\end{tabular}

1 Påvirker serumkonsentrasjonen

2 Påvirker effekten

likhet med metadon føre til forlenget QT-tid, og forsiktighet bør derfor utvises ved samtidig behandling med disse legemidlene.

\section{Antiepileptika}

Karbamazepin, fenytoin og fenobarbital er alle indusere av CYP-systemet, og er vist å kunne senke konsentrasjonen av metadon (10-12), og trolig også av buprenorfin. Fenobarbital og klonazepam kan i tillegg gi additive dempende effekter.

\section{Antibiotika og antimykotika}

Disse gruppene interagerer generelt i liten grad med metadon og buprenorfin, men også her er det noen interaksjoner som kan være relevante. Ciprofloksacin hemmer CYP 1A2 og CYP 3A4, og er vist å kunne øke serumkonsentrasjonen av metadon (13). Flukonazol kan også gi økt serumkonsentrasjon av metadon (14). Ketokonazol er i in vitro-studier vist å hemme metabolismen av buprenorfin og metadon via CYP3A4 $(15,16)$, og 
kan dermed potensielt øke serumkonsentrasjonen av legemidlene. Erytromycin og klaritromycin, som teoretisk sett også kan øke serumkonsentrasjonene av metadon og buprenorfin ved å være hemmere av CYP3A4, samt azitromax, kan i likhet med metadon føre til forlenget QT-tid og torsades de pointes (17).

\section{Antiretrovirale legemidler}

Alle de tre gruppene av antiretrovirale legemidler (nukleosid/nukleotid reverstranskriptasehemmere, ikke-nukleotid reverstranskriptasehemmere og proteasehemmere) har vist seg å interagere med metadon og buprenorfin. Generelt har buprenorfin færre klinisk relevante interaksjoner med disse legemidlene enn metadon. Ved kombinasjon av antiretrovirale legemidler og metadon/buprenorfin bør pasientene uansett følges nøye med tanke på tegn til overdosering eller abstinensplager, og serumkonsentrasjonsmålinger bør foretas. Før oppstart kan de forskjellige legemidlene sjekkes i interaksjonsdatabaser, som www.hiv-druginteractions.org $(3,18)$.

\section{Benzodiazepiner}

Benzodiazepiner blir relativt ofte inntatt sammen med metadon og buprenorfin, og konsekvensene kan i verste fall være fatale. Det later ikke til at benzodiazepiner påvirker farmakokinetikken til metadon eller buprenorfin i noen særlig grad, slik at interaksjonene i hovedsak er av farmakodynamisk karakter (19).

\section{Andre}

Utover de nevnte legemiddelgrupper er det flere grupper som kan gi additive dempende effekter (som f.eks. andre opioider) og forlenget QT-tid (f.eks. flere antiarytmika).

\section{Konklusjon}

Generelt later det til at buprenorfin av farmakokinetiske grunner har relativt få klinisk relevante interaksjoner, mens det ved behandling med metadon er grunn til å være mer oppmerksom på denne problematikken.

Når det gjelder metadon er det hovedsakelig to forhold det er viktig å være oppmerksom på da disse kan få alvorlige og i verste fall dødelige konsekvenser: for det første overdosering grunnet enzymhemming, og sedasjon og respirasjonshemming ved samtidig behandling med dempende legemidler, for det andre behandling med andre legemidler som kan føre til forlenget QT-tid og torsades de pointes. For buprenorfin bør man være oppmerksom ved samtidig behandling med dempende legemidler, som benzodiazepiner. I de tilfeller der det er nødvendig å bruke legemidler som kan interagere, kan dosejustering ved tegn til overdosering eller abstinensplager være påkrevd. Det kan uansett være nyttig å konsultere interaksjonsdatabaser, som for eksempel DRUID (www.interaksjoner.no).

\section{Eirin Bakke}

\section{Liliana Bachs}

liliana.bachs@fhi.no

Divisjon for rettstoksikologi og

rusmiddelforskning

Nasjonalt folkehelseinstitutt

Postboks 4404 Nydalen

0403 Oslo

Oppgitte interessekonflikter: Ingen

\section{Litteratur}

1. Spigset O, Molden E. Cytokrom P-450 3A4 - kroppens viktigste arena for legemiddelinteraksjoner. Tidsskr Nor Lægeforen 2008; 128: 2832-5.

2. Ferrari A, Coccia CP. Bertolini A et al. Methadone - metabolism, pharmacokinetics and interactions.Pharmacol Res 2004; 50: 551 -9

3. Bruce RD, McCance-Katz E, Kharasch ED et al. Pharmacokinetic interactions between buprenorphine and antiretroviral medications. Clin Infect Dis 2006; 43 (suppl 4): 216-23.

4. Elkader A, Sproule B. Buprenorphine: clinical pharmacokinetics in the treatment of opioid dependence. Clin Pharmacokinet 2005; 44: 661-80.

5. Begre S, von BU, Ladewig D et al. Paroxetine increases steady-state concentrations of $(R)$-methadone in CYP2D6 extensive but not poor metabolizers. J Clin Psychopharmacol 2002; 22: 211-5.

6. Hamilton SP, Nunes EV, Janal M et al. The effect of sertraline on methadone plasma levels in methadone-maintenance patients. Am J Addict 2000; 9: $63-9$

7. Iribarne C, Picart D, Dreano Y et al. In vitro interactions between fluoxetine or fluvoxamine and methadone or buprenorphine. Fundam Clin Pharmacol 1998; 12: 194-9.

8. Gillman PK. Monoamine oxidase inhibitors, opioid analgesics and serotonin toxicity. $\mathrm{Br} J$ Anaesth 2005; 95: 434-41.

9. Krantz MJ, Kutinsky IB, Robertson AD et al. Doserelated effects of methadone on QT prolongation in a series of patients with torsade de pointes. Pharmacotherapy 2003; 23: 802-5

10. Liu SJ, Wang RI. Case report of barbiturateinduced enhancement of methadone metabolism and withdrawal syndrome. Am J Psychiatry 1984; 141: 1287-8.

11. Saxon AJ, Whittaker S, Hawker CS. Valproic acid, unlike other anticonvulsants, has no effect on methadone metabolism: two cases. J Clin Psychiatry 1989; 50: 228-9.

12. Tong TG, Pond SM, Kreek MJ et al. Phenytoininduced methadone withdrawal. Ann Intern Med 1981; 94: 349-51

13. Herrlin K, Segerdahl M, Gustafsson LL et al. Methadone, ciprofloxacin, and adverse drug reactions. Lancet 2000; 356: 2069-70.

14. Cobb MN, Desai J, Brown LS jr. et al. The effect of fluconazole on the clinical pharmacokinetics of methadone. Clin Pharmacol Ther 1998; 63: $655-62$

15. Iribarne C. Picart D, Dreano Y et al. Involvement of cytochrome P450 3A4 in N-dealkylation of buprenorphine in human liver microsomes. Life Sci 1997; 60: 1953-64.

16. Moody DE, Alburges ME, Parker RJ et al. The involvement of cytochrome P450 3A4 in the $\mathrm{N}$-demethylation of $\mathrm{L}$-alpha-acetylmethadol (LAAM), norLAAM, and methadone. Drug Metab Dispos 1997; 25: 1347-53.

17. Ray WA, Murray KT, Meredith S et al. Oral erythromycin and the risk of sudden death from cardiac causes. N Engl J Med 2004; 351: 1089-96.

18. McCance-Katz EF. Treatment of opioid dependence and coinfection with HIV and hepatitis C virus in opioid-dependent patients: the importance of drug interactions between opioids and antiretroviral agents. Clin Infect Dis 2005; 41 (suppl 1) 89-95.

19. Lintzeris N, Mitchell TB, Bond A et al. Interactions on mixing diazepam with methadone or buprenorphine in maintenance patients. J Clin Psychopharmacol 2006; 26: 274-83 